\title{
DAMPAK ROTATING TRIO EXCHANGE DAN CURIOSITY TERHADAP PEMAHAMAN KONSEP
}

\section{THE IMPACT OF ROTATING TRIO EXCHANGE AND CURIOSITY ON CONCEPT UNDERSTANDING}

\author{
Dhika Rayi Artania ${ }^{a}$, Ruhban Masykur ${ }^{\mathrm{b}}$, Siska Andrianic \\ a Program Studi Pendidikan Matematika FTK UIN RIL \\ J1. Endro Suratmin, Sukarame, Lampung, dhikarayi25@gmail.com \\ b Program Studi Pendidikan Matematika FTK UIN RIL \\ Jl. Endro Suratmin, Sukarame, Lampung, rmasykur@yahoo.co.id \\ c Program Studi Pendidikan Matematika FTK UIN RIL \\ Jl. Endro Suratmin, Sukarame, Lampung, siskaandriani@radenintan.ac.id
}

\begin{abstract}
ABSTRAK
Kemampuan pemahaman konsep matematis ialah suatu kemampuan yang penting dalam matematika. Tujuan yang ingin dicapai pada penelitian ini ialah untuk mengetahui dampak model pembelajaran Rotating Trio Exchange (RTE) dan Curiosity terhadap pemahaman konsep matematis peserta didik SMP. Penelitian ini ialah penelitian kuantitatif. Populasi dipenelitian ini ialah seluruh kelas VIII MTs Ma'arif NU 5 Sekampung. Sampel yang digunakan ialah kelas VIII.A sebagai kelas eksperimen menggunakan model pembelajaran Rotating Trio Exchange (RTE) dan kelas VIII.B sebagai kelas kontrol dengan model pembelajaran ekspositori. Teknik pengumpulan data menggunakan tes kemampuan pemahaman konsep matematis serta angket curiosity. Uji hipotesis menggunakan anava dua jalan dengan sel tak sama. Uji normalitas dengan uji Liliefors dan uji homogenitas dengan uji Barlett. Dari hasil analisis diperoleh $\mathrm{H}_{0 \mathrm{~A}}$ ditolak, $\mathrm{F}_{\text {hitung }}>\mathrm{F}_{\text {tabel }}$ yaitu 10,285 $>$ 4,13. Dengan begitu, ada dampak model pembelajaran Rotating Trio Exchange (RTE) terhadap pemahaman konsep matematis peserta didik. $\mathrm{H}_{0 \mathrm{~B}}$ ditolak, $\mathrm{F}_{\text {hitung }}>\mathrm{F}_{\text {tabel }}$ yaitu 51,53 $>3,28$. Dengan begitu, ada dampak Curiosity terhadap pemahaman konsep matematis peserta didik. $\mathrm{H}_{0 \mathrm{AB}}$ diterima, $\mathrm{F}_{\text {hitung }}<\mathrm{F}_{\text {tabel }}$ yaitu $0,36<3,28$. Dengan begitu tak ada interaksi antara Rotating Trio Exchange (RTE) dan Curiosity terhadap pemahaman konsep matematis peserta didik.
\end{abstract}

Kata Kunci : Curiosity, Pemahaman Konsep Matematis, Rotating Trio Exchange.

\section{ABSTRACK}

The ability to understand mathematical concepts is an important ability in mathematics. The aim of this study is to determine the effect of the Rotating Trio Exchange (RTE) and Curiosity learning model on the understanding of mathematical concepts of junior high school students. This research is quantitative research. The population in this study were all class VIII MTs Ma'arif NU 5 Sekampung. The sample used is class VIII.A as an experimental class using the Rotating Trio Exchange (RTE) learning model and class VIII.B as a control class with an expository learning model. The data collection technique used a mathematical concept understanding ability test and a curiosity questionnaire. Hypothesis testing using two-way ANOVA with unequal cells. Normality test with Liliefors test and homogeneity test with Barlett test. From the results of the analysis obtained HOA is rejected, Fcount > Ftable that is $10.285>4.13$. That way, there is an effect of the Rotating Trio Exchange (RTE) learning model on students' understanding of mathematical concepts. HOB is rejected, Fcount > Ftable, which is $51.53>3.28$. That way, Curiosity has an influence on students' understanding of mathematical concepts. HOAB is accepted, Fcount $<$ Ftable that is $0.36<3.28$. That way there is no interaction between Rotating Trio Exchange (RTE) and Curiosity on students' understanding of mathematical concepts.

Keywords: Curiosity, Ability to Understand Mathematical Concepts, Rotating Trio Exchange. 


\section{Pendahuluan}

Menurut Undang-Undang Nomor 20 tahun 2003 tentang sistem pendidikan menjelaskan bahwa pendidikan merupakan suatu usaha sadar yang telah direncanakan supaya bisa mewujudkan suasana dalam proses belajar mengajar agar peserta didik dapat menjadi aktif mengembangkan potensi yang dimiliki oleh dirinya agar memiliki kekuatan spiritual, keagamaan, pengendalian diri, kecerdasan, akhlak mulia, serta memiliki keterampilan yang dibutuhkan oleh dirinya, masyarakat, bangsa serta negara (Widyawati, 2016). Tanpa adanya pendidikan manusia akan lebih sukar untuk tumbuh, sehingga dapat menyebabkan mereka menjadi tertinggal (Sri Anggoro, 2016). Pendidikan memiliki tujuan yang berguna untuk menopang pelajar menumbuhkan kemampuan yang ada pada dirinya (Masykur, Rosidin, dan Iqbal 2018). Satu di antara ilmu pengetahuan yang wajib diketahui oleh kita ialah ilmu matematika.

Matematika merupakan satu di antra ilmu yang berguna untuk kehidupan sehari-hari (Andriani, 2015). Matematika merupakan salah satu mata pelajaran yang sangat penting dan wajib kita pelajari sejak taman kanak-kanak hingga tingkat perguruan tinggi (Ganda Putra, 2016). Matematika memiliki peranan dalam tolak ukur ilmu pengetahuan (Yahya dan Bakri, 2020). Pembelajaran dalam matematika ialah pembelajaran yang memiliki konsep yang tersusun. Interaksi antara pendidik dengan peserta didik merupakan bukti bahwa telah terjadi proses pembelajaran. Para ahli telah meneliti bahwa interaksi antara pendidik dengan peserta didik yang memiliki keterkaitan dengan bahan pembelajaran ialah model pembelajaran.

Model pembelajaran adalah sesuatu yang sebelumnya telah direncanakan dan memiliki pola yang berguna untuk melangsungkan kurikulum, merancang bahan-bahan untuk proses belajar mengajar, membimbing pembelajaran di kelas yang lain (Nurdyansyah dan Fariyarul Fahyuni, 2016). Model pembelajaran yang dipakai dalam penelitian ini ialah model pemebelajaran Rotating Trio Exchange.

Rotating Trio Exchange ialah satu di antara model pembelajaran yang digunakan oleh pendidik di dalam kelas, model pembelajaran ini berbentuk kelompok dimana setiap kelompok beranggotakan tiga orang peserta didik (Ekawati, 2018). Pembelajaran ini menggunakan teknik rotasi. Dengan adanya perrotasian antar anggota kelompok seperti ini, diharapkan agar 
dapat menambah keaktifan peserta didik dalam pembelajaran (Khanafiyah, 2011).

Menurut Peraturan Menteri Pendidikan Nasional Nomor 22 tahun 2006, menjelaskan bahwa target awal dari pembelajaran matematika adalah paham dengan adanya konsep matematika, dapat memperjelas keterkaitan konsep matematika dan mengaplikasikan konsep tersebut dengan benar dalam pemecahan suatu pertanyaan. Jadi dapat disimpulkan bahwa pemahaman konsep matematis merupakan bagian yang paling penting dalam pembelajaran matematika (Herawati dan Siroj, 2010).

Pemahaman konsep matematis merupakan salah satu hal yang penting dalam matematika. Pemahaman konsep adalah suatu kemampuan yang harus dikuasai oleh setiap peserta didik dalam pembelajaran matematika. Pemahaman konsep matematis dapat menentukan berhasil atau tidaknya para peserta didik dalam belajar matematika (Dewi Purwanti, Dinda Pratiwi, dan Rinaldi 2016). Dengan hal tersebut, jika terdapat peserta didik yang belum menguasai konsep dasar dalam matematika, maka peserta didik tersebut akan merasa kesulitan untuk menguasai konsep yang lebih lanjut(Suherman, 2015). Selain pemahaman konsep matematis peserta didik, satu di antara syarat agar proses belajar mengajar dikatakan berhasil ialah dengan adanya faktor, contohnya seperti minat, motivasi, rasa ingin tahu (curiosity), kecerdasan dan sebagainya.

Curiosity merupakan hal penting yang dapat mendorong serta membantu dalam pembuatan ide-ide baru, presepsi, representasi, dan inovasi agar menjadi lebih kreatif dan dapat berpikir divergen. Curiosity adalah keinginan serta kebutuhan yang ada didiri seseorang untuk mengetahui dan memperoleh jawaban dari suatu pertanyaan yang dapat menimbulkan keingintahuan yang mendalam. Curiosity peserta didik dapat ditingkatkan dengan cara memberikan demonstrasi pada awal pembelajaran (Ismawati, Nugroho, dan Dwijananti, 2014). Dengan begitu dapat dijelaskan bahwa jika peserta didik memiliki rasa ingin tahu (curiosity) yang tinggi, maka tujuan dari suatu proses dalam belajar mengajar dapat dicapai dengan lebih mudah (Ali Husni, 2014).

Bersumber dari kesimpulan wawancara yang telah peneliti lakukan dengan Ibu Ratna selaku pendidik yang mengajar matematika, beliau mangatakan bahwa di MTs Ma'arif NU 5 Sekampung masih menerapkan model pembelajaran secara umum seperti ekspositori, dan hanya berpusat pada pendidik serta belum pernah menggunakan model Rotating 
Trio Exchange. Hal tersebut menyebabkan metode dalam pembelajaran menjadi cenderung pasif, bosan, dan membuat peserta didik sungkan untuk menanyakan serta membuat peserta didik menjadi kurang memahami konsep awal sehingga kemampuan pemahaman konsep matematis peserta didik masih tergolong rendah. Beliau juga mengatakan bahwa ada peserta didik yang lupa, bahkan belum paham materi yang diajarkan dijenjang Sekolah Dasar.

Hal ini dapat dilihat pada hasil tes uji coba pemahaman konsep matematis yang diperoleh oleh peserta didik kelas VIII MTs Ma'arif NU 5 Sekampung nilainya masih banyak di bawah KKM yaitu 70 , peserta didik yang memeroleh nilai di atas KKM hanya ada tiga orang peserta didik saja.

Rendahnya kemampuan pemahaman konsep matematis peserta didik dapat disebabkan oleh model pembelajaran yang masih menggunakan metode ekspositori, yaitu pembelajaran yang berpusat kepada pendidik, peserta didik cenderung pasif. Selain memperoleh hasil dari tes kemampuan pemahaman konsep matematis, peneliti juga memperoleh informasi bahwa curiosity (rasa ingin tahu) peserta didik di MTs Ma'arif NU 5 Sekampung masih tergolong rendah. Hal tersebut dibuktikan dengan hasil dari angket yang telah peneliti berikan kepada peserta didik pada saat uji coba penelitian dilakukan.

Bersumber dari latar belakang masalah dan rumusan masalah, maka penelitian ini bertujuan:

1. Untuk mengetahui apakah ada dampak penggunaan model pembelajaran Rotating Trio Exchange terhadap pemahaman konsep matematis peserta didik.

2. Untuk mengetahui apakah ada dampak Curiosity terhadap pemahaman konsep matematis peserta didik.

3. Untuk mengetahui apakah ada interaksi antara Rotating Trio Exchange dan Curiosity terhadap pemahaman konsep matematis peserta didik.

\section{Metode Penelitian}

Penelitian ini menggunakan penelitian kuantitatif, sebab data yang didapat berbentuk angka-angka dan akan dianalisis menggunakan statistik dan penelitian ini termasuk dalam penelitian eksperimen semu atau Quasy Experimental Design, yang terdiri dari kelas eksperimen dan kelas kontrol sebagai kelas pembanding (Wahyu Yunian Putra, 2016). Subyek pada 
penelitian ini ialah peserta didik kelas VIII MTs Ma'arif NU 5 Sekampung.

Penelitian ini hendak

menggunakan dua kelas dengan perlakuan yang tidak sama. Kelompok kelas pertama yang bertindak sebagai kelas eksperimen menggunakan model pembelajaran Rotating Trio Exchange, sedangkan kelompok kelas kedua yang bertindak sebagai kelas kontrol menggunakan pembelajaran ekspositori.

Instrumen yang dipakai untuk penelitian ini menggunakan tes uraian kemampuan pemahaman konsep matematis serta angket curiosity (rasa ingin tahu). Tes yang digunakan bersumber dari indikator pemahaman konsep matematis, yaitu 1) Menyatakan ulang setiap konsep. 2) Mengklasifikasikan obyek-obyek menurut karakter yang terpilih, sesuai dengan konsep yang ada. 3) Memberikan yang tergolong contoh dan bukan contoh dari setiap konsep. 4) Menampilkan konsep dalam bermacam-macam bentuk representasi matematis. 5) Menguraikan ketentuan wajib atau ketentuan layak konsep. 6) Memakai serta memutuskan prosedur atau operasi tertentu. 7) Menerapkan konsep atau algoritma pemecahan masalah (Dinda Pratiwi, 2016).

\section{Hasil dan Pembahasan}

Pada proses pengumpulan data, peneliti meneliti peserta didik kelas VIII di MTs Ma'arif NU 5 Sekampung yang terdapat pada kelas VIII.A dan VIII.B. Populasi pada penelitian ini ialah seluruh peserta didik kelas VIII MtsMa'arif NU 5 Sekampung. Obyek pada penelitian ini ialah pembelajaran Rotating Trio Exchange $\left(\mathrm{X}_{1}\right)$ dan Curiosity $\left(\mathrm{X}_{2}\right)$ sebagai variabel terikat, serta pemahaman konsep matematis peserta didik sebagai variabel bebas (Y).

Teknik pengumpulan data pada penlitian ini memakai tes serta angket. Peneliti memberikan soal pemahaman konsep matematis sebanyak 8 soal kepada peserta didik dan angket curiosity yang berjumlah 15 buah pernyataan untuk mereka kerjakan dan diisi menurut apa yang mereka rasakan.

Hasil yang diperoleh dari analisis pemahaman konsep matematis peserta didik pada materi pola bilangan kelas VIII MTs Ma'arif NU 5 Sekampung bisa dilihat pada tabel 1 di bawah ini:

Tabel 1. Rata-rata Kemampuan Pemahaman Konsep Matematis Peserta Didik

\begin{tabular}{ccc}
\hline No & Kelas & Rata-rata \\
\hline 1 & VIII.A (Eksperimen) & 77,9 \\
\hline 2 & VIII.B (Kontrol) & 68,95 \\
\hline
\end{tabular}


Tabel 1. di atas menyatakan bahwa kelas VIII.A sebagai kelas eksperimen yang menggunakan model pembelajaran Rotatig Trio Exchange nilai rata-rata nya lebih besar daripada kelas VIII.B sebagai kelas kontrol yang menggunakan model pembelajaran ekspositori.

Bersumber dari hasil pengujian anava dua jalan dengan sel tak sama dapat dilihat rangkuman pada tabel 2. di bawah:

Tabel 2. Rangkuman Anava Dua Jalan dengan Sel Tak Sama

\begin{tabular}{ccccccc}
\hline Sumber & JK & dk & RK & Fobs $_{\text { }}$ & F $\boldsymbol{\alpha}$ & P \\
\hline Model Pembelajaran & 1120,68 & 1 & 1120,68 & 10,285 & 4,13 & $<0,05$
\end{tabular}

(A)

\begin{tabular}{ccccccc}
\hline Curiosity (B) & 11230,81 & 2 & 5615,40 & 51,53 & 3,28 & $<0,05$ \\
\hline Interaksi (AB) & 78,53 & 2 & 39,266 & 0,36 & 3,28 & $>0,05$ \\
\hline Galat & 3704,64 & 34 & 108,96 & & & \\
\cline { 1 - 3 } Total & 16134,67 & 39 & \multicolumn{1}{c}{} & & &
\end{tabular}

Menurut hasil dari perhitungan

analisis variansi dua jalan dengan sel tak sama di atas, maka dapat diartikan bahwa:

1. HoA ditolak. Menurut perhitungan analisis variansi dua jalan dengan sel tak sama bahwa $F_{\text {obs }}=10,285$ dan $\mathrm{F} \alpha$ $=4,13$. Kondisi tersebut membuktikan bahwa Fhitung $>$ Ftabel sehingga $\mathrm{F} \alpha$ adalah $\mathrm{DK}=\{\mathrm{F} \mid \mathrm{F}>4,13\}$. Dengan begitu, ada dampak model pembelajaran Rotating Trio Exchange terhadap pemehaman konsep matematis peserta didik.

2. $\mathrm{H}_{0 \mathrm{~B}}$ ditolak. Menurut perhitungan analisis variansi dua jalan dengan sel tak sama bahwa $\mathrm{F}_{\mathrm{obs}}=51,53$ dan $\mathrm{F} \alpha=$ 3,28. Kondisi tersebut membuktikan bahwa $F_{\text {hitung }}>\mathrm{F}_{\text {tabel }}$ sehingga $\mathrm{F} \alpha$ adalah $\mathrm{DK}=\{\mathrm{F} \mid \mathrm{F}>3,28\}$. Dengan begitu, ada dampak Curiosity terhadap pemahaman konsep matematis siwa.

3. $\mathrm{H}_{0 \mathrm{AB}}$ diterima. Menurut perhitungan analisis variansi dua jalan dengan sel tak sama bahwa $\mathrm{F}_{\mathrm{obs}}=0,36$ dan $\mathrm{F} \alpha=$ 3,28. Kondisi tersebut membuktikan bahwa $F_{\text {hitung }}<F_{\text {tabel }}$ sehingga $\mathrm{F} \alpha$ adalah $\mathrm{DK}=\{\mathrm{F} \mid \mathrm{F}<3,28\}$. Dengan begitu, tidak ada interaksi antara Rotating Trio Exchange dan Curiosity terhadap pemahaman konsep matematis peserta didik.

Penelitian ini dilaksanakan guna mendapatkan informasi dari eksperimen yang telah peneliti laksanakan. Fungsi dari penelitian ini ialah untuk menguji dampak model pembelajaran Rotating Trio Exchange dan Curiosity terhadap pemahaman konsep matematis peserta didik SMP. 
1. Analisis Hipotesis Pertama

Ada dampak model pembelajaran

Rotating Trio Exchange terhadap

pemehaman konsep matematis

peserta didik. Model

pembelajaran Rotating Trio

Exchange ialah model yang mana

peserta didik akan bekerjasama

bersama kelompok yang lainnya.

Pada saat jalannya pembelajaran

di MTs Ma'arif NU 5 Sekampung

yang memakai pembelajaran

Rotating Trio Exchange, peserta

didik menjadi lebih aktif selama

pelajaran matematika. Peserta

didik membahas dengan teman

kelompoknya serta berdiskusi

mengenai kesimpulan yang akan

diambil, dan dapat membahas

dengan teman yang ada pada

kelompok lainnya. Pendidik

hanya mengajukan saran terhadap

peserta didik. Ketika

pembelajaran sedang

dilaksanakan jika ada di antara

peserta didik yang menanyakan

tentang soal-soal yang kurang

dipahami, maka yang menjawab

pertanyaannya ialah peserta didik

yang lainnya. Melalui cara

tersebut peserta didik akan

menjelaskan kembali konsep yang

sudah dijelaskan sebelumnya

oleh pendidik ke peserta didik lainnya. Kemampuan pemahaman konsep ialah satu di antara kemampunya yang wajib peserta didik kuasai dipelajaran matematika.

2. Analisis Hipotesis Kedua

Ada dampak Curiosity terhadap pemahaman konsep matematis peserta didik. Keingin tahuan peserta didik akan mendorong peserta didik untuk terus mencari tahu dan memahami masalah terkini sehingga menambah ilmu pengetahuan serta keahlian dalam proses belajar. Menurut hasil penelitian dengan memahami konsep matematis peserta didik bisa mencukupi rasa ingin tahu peserta didik tentang masalah yang belum didapati terpaut materi pada pelajaran matematika. Menurut penelitian yang telah dilaksanakan, curiosity yang tidak sama dengan teori yang tertera dikarenakan sejumlah faktor di antara ada beberapa dari peserta didik yang mengisi angket tidak sama dengan kepribadian dari peserta didik itu sendiri. Kondisi tersebut menjadikan 
pengelompokan peserta didik tidak sinkron dengan teori dan hasil dari penelitian. Peserta didik yang memiliki curiosity tinggi di kelas eksperimen dan kontrol boleh jadi sesungguhnya ialah peserta didik yang memiliki curiosity sedang sperti itupun sebaliknya. Namun, peserta didik yang memiliki curiosity tinggi dan rendah memiliki efek yang lain untuk kelas eksperimen dan kontrol.

\section{Analisis Hipotesis Ketiga}

Tidak ada perbedaan interaksi antara Rotating Trio Exchange dan Curiosity terhadap pemahaman konsep matematis peserta didik. Menurut teori yang telah dipaparkan, yang dapat memengaruhi pemahaman konsep matematis peserta didik serta curiosity ialah model pembelajaran Rotating Trio Exchange. Peserta didik yang memiliki curiosity tinggi lebih cocok apabila memakai model pembelajaran Rotating Trio Exchange, namun tidak dianjurkan bagi peserta didik yang memiliki curiosity rendah. Kondisi seperti ini diakibatkan oleh model pembelajaran Rotating Trio Exchange mewajibkan peserta didik aktif dalam memahami konsep pembelajaran matematika. Proses pembelajaran yang tertera diharapkan mampu meningkatkan pemahman konsep matematis peserta didik.

Bersumber dari teori yang telah disampaikan, peserta didik yang memiliki rasa ingin tahu yang tinggi menjadi gampang untuk menerapkan model pembelajaran Rotating Trio Exchange ketimbang menggunakan strategi pembelajaran ekspositori, namun peserta didik yang memiliki curiosity rendah menjadi sukar jika diterapkannya model pembelajaran yang digunakan. Hasil penelitian yang telah dilaksanakan peneliti menjelaskan bahwa tidak ada interaksi antara model pembelajaran Rotating Trio Exchange dan curiosity terhadap pemahman konsep matematis peserta didik.

Tidak sesuainya hasil penelitian disebabkan oleh beberapa faktor, yaitu lingkungan pada saat pembelajaran kurang kondusif, ruang belajar yang kurang 
nyaman sehingga dapat menyebabkan konsentrasi peserta didik terganggu. Beberapa faktor tersebut memberikan dampak terhadap hasil penelitian yang ridak selaras dengan teori.

\section{Kesimpulan}

Bersumber dari hasil menganalisis data yang penulis temukan perihal dampak model pembelajaran Rotating Trio Exchange dan Curiosity terhadap pemahaman konsep matematis peserta didik SMP kelas VIII MTs Ma'arif NU 5 Sekampung pada pokok bahasan Pola Bilangan ditemukan bahwa:

1. Ada dampak model Rrotating Trio Exchange terhadap kemampuan pemahaman onsep matematis peserta didik. Peserta didik yang menerima pembelajaran menggunakan model Rotating Trio Exchange mempunyai kemampuan pemahaman konsep matematis yang lebih baik dibandingkan dengan peserta didik yang menerima pembelajaran ekspositori.

2. Ada dampak dari Curiosity terhadap kemampuan pemahaman konsep matematis peserta didik. Kemampuan pemahaman konsep matematis peserta didik yang mempunyai Curiosity tinggi lebih baik dibandingkan peserta didik yang mempunyai Curiosity rendah.

3. Tidak ada interaksi antara model Rotating Trio Exchange dan Curiosity terhadap pemahaman konsep matematis peserta didik.

\section{Ucapan Terima Kasih}

Pada penelitian ini, peneliti mengucapkan terima kasih untuk peserta didik kelas VIII di MTs Ma'arif NU 5 Sekampung yang sudah bersedia menjadi sampel untul penelitian ini. Peneliti juga mengucapkan terima kasih kepada seluruh pihak yang telah terlibat untuk penulisan skripsi ini.

\section{Pustaka}

Ali Husni, Moh. (2014). Keefektifan Pembelajaran Matematika dengan Problem Posing dan Problem Solving Ditinjau dari Prestasi dan Curiosity. Phytagoras: Jurnal Pendidikan Matematika , 11-21.

Andriani, Siska. (2015). Evaluasi CSEUCLA pada Studi Proses Pembelajaran Matematika. $A l$ Jabar: Jurnal Pendidikan Matematika , 167-175.

Arifin, dan S. Khanafiyah. (2011). Penerapan Model Pembelajaran Aktif Melaluli Strategi Rotating Trio Exchange untuk 
Meningkatkan Kemampuan

Analisis dan Aktivitas Belajar

Peserta didik SMA kelas $\mathrm{X}$

Semester II Pokok Bahasan Kalor.

Jurnal Pendidikan Fisika

Indonesia , 97-100.

Dewi Purwanti, Ramadhani, Dona Dinda

Pratiwi, dan Achi Rinaldi. (2016).

Pengaruh Pembelajaran

Berbantuan Geogebra terhadap

Pemahaman Konsep Matematis

ditinjau dari Gaya Kognitif , $A l$ -

Jabar: Jurnal Pendidikan

Matematika 115-122.

Dinda Pratiwi, Dona. (2016).

Pembelajaran Learning Cycle 5e

berbantuan Geogebra terhadap

Kemampuan Pemahaman Konsep

Matematis. Al-Jabar: Jurnal

Pendidikan Matematika , 191202.

Ekawati, Sri. (2018). Penggunaan Model

Pembelajaran Kooperatif Tipe

Rotating Trio Exchange untuk

Meningkatkan Hasil Belajar

Ekonomi pada Topik Persamaan

Dasar Akuntansi. Jurnal

Pendidikan Tambusai , 167-184.

Ganda Putra, Fredi. (2016). Pengaruh

Model Pembelajaran Reflektif

dengan Pendekatan Matematika

Realistik Bernuansa Keislaman terhadap

Kemampuan
Komunikasi Matematis. Aljabar:

Jurnal Pendidikan Matematika , 203-210.

Herawati, Oktiana Dwi Putra, dan Rusdy Siroj. (2010). Pengaruh Pembelajaran Problem Posing Terhadap Kemampuan Pemahaman Konsep Matematika Siswa Kelas XI IPA SMA Negeri 6 Palembang, 11.

Ismawati, F, S.E. Nugroho, dan P. Dwijananti. (2014). Penerapan Model Pembelajaran Conceptual Understanding Procedures untuk Meningkatkan Curiosity dan Pemahaman Konsep Matematis Siswa. Jurnal Pendidikan Fisika Indonesia , 22-27.

Masykur, Ruhban, Undang Rosidin, dan Agung M Iqbal. (2018). Implementasi Kurikulum KKNI Pada Program Studi Matematika Universitas Islam Negeri Raden Intan Lampung. NUMERICAL: Jurnal Matematika dan Pendidikan Matematika, 7-12.

Nurdyansyah, dan Eni Fariyarul Fahyuni. (2016). Inovasi Model Pembelajaran. Nizamia Learning Center.

Sri Anggoro, Bambang. (2016). Meningkatkan Kemampuan Generalisasi Matematis Melalui 
Discovery Learning dan Model

Peer Led Guided Inquiry. Al-

Jabar: Jurnal Pendidikan

Matematika , 11-20.

Suherman. (2015). Kreativitas Siswa dalam Memecahkan Masalah Matematika Materi Pola Bilangan dengan Pendekatan Matematika Realistik (PMR). Al-Jabar: Jurnal Pendidikan Matematika, 81-90.

Wahyu Yunian Putra, Rizki. (2016). Pembelajaran Matematika dengan Metode Accelerated Learning untuk meningkatkan Kemampuan Penalaran Adatif. Jurnal Pendidikan Matematika, 215.

Widyawati, Santi. (2016. )Pengaruh Gaya Belajar Terhadap Prestasi Belajar Mahasiswa Program Studi Pendidikan Matematika (IAIM NU) Metro. Al-Jabar: Jurnal Pendidikan Matematika , 107114.

Yahya, Amran, dan Nur Wahidah Bakri. (2020). Pembelajaran Kooperatif Tipe Rotating Trio Exchange untuk Meningkatkan Aktivitas dan Hasil Belajar Matematika Siswa. Jurnal Analisa , 69-79. 
